\title{
Blood typing and haematological analysis of domestic feline donors
}

\section{Tipagem sanguínea e análise hematológica de felinos domésticos doadores de sangue}

\author{
Darlan Henrique Canei ${ }^{1}$; Marcela Natacha Aparecida Rocha ${ }^{1}$; Samilla Juliana \\ Barbosa Barroso ${ }^{2}$; Paulo Victor Braga de Almeida Santos ${ }^{1}$; Náthalye Fernandes \\ Pelegrini $^{1}$; Mariana Elisa Pereira ${ }^{1}$; Valéria Régia Franco Sousa ${ }^{3}$; Adriane Jorge \\ Mendonça $^{3}$; Arleana do Bom Parto Ferreira de Almeida ${ }^{3 *}$
}

Highlights:

In this research conducted on felines selected as blood donors, 100\% had blood type A.

Felines had a body score, age, and weight considered ideal for blood donation.

Blood donation felines did not present with anaemia, but thrombocytopenia was common.

\begin{abstract}
Blood typing is critical to avoid adverse reactions to transfusions. Felines have three blood-types: A, B, and $\mathrm{AB}$ and have natural alloantibodies the opposite blood type, in addition to the Mik type described recently. The presence of alloantibodies is important in the selection of blood donors in order to minimize the occurrence of transfusion reactions, and blood typing is essential in this context. This study aimed to identify blood types and perform a haematological analysis of feline blood donor candidates. Sixty clinically healthy felines of different races, weighing more than four kilograms, and ranging from one to eight years old, were evaluated. After clinical evaluation, blood samples were collected for hemogram and blood typing with the LabTest $\mathrm{A}+\mathrm{B}^{\circledR}$ immunochromatographic test. All cats had a haematocrit level within normal range (mean: $34.12 \%$ ), six $(10 \%)$ presented with leucocytosis and $24(40 \%)$ with thrombocytopenia, reinforcing the importance of haematological monitoring of blood donor animals. Regarding blood typing, all domestic felines selected as blood donors had type A blood. This is the first study on frequencies of feline blood types performed in the region.
\end{abstract}

Key words: Transfusion. Cats. Blood. AB blood group.

\section{Resumo}

A tipagem sanguínea é fundamental para evitar reações adversas a transfusões. Os felinos possuem três tipos sanguíneos, $\mathrm{A}, \mathrm{B}$ e AB, onde o felino apresenta a presença de aloanticorpos naturais contra o tipo sanguíneo que não possui, além do tipo Mik descrito recentemente. A presença de aloanticorpos é importante no que se refere à seleção de doadores de sangue com vista a minimizar ocorrência de

\footnotetext{
1 Discentes de Residência, Programa de Residência Uniprofissional em Medicina Veterinária, Faculdade de Medicina Veterinária, Universidade Federal de Mato Grosso, UFMT, Cuiabá, MT, Brasil. E-mail: darlancanei@hotmail.com; marcelanatachavet@ gmail.com; pvbraguinha@gmail.com; nathypelegrini@gmail.com; marianaep@gmail.com

2 Discente do Curso de Graduação em Medicina Veterinária, Faculdade de Medicina Veterinária, Universidade Federal de Mato Grosso, UFMT, Cuiabá, MT, Brasil. E-mail: samilla barroso@hotmail.com

3 Prof $^{\text {as }} \operatorname{Dr}^{\text {as }}$, Faculdade de Medicina Veterinária, Universidade Federal de Mato Grosso, UFMT, Cuiabá, MT, Brasil. E-mail: valeriaregia27@gmail.com, adrianejorge.m@gmail.com; arleferreira@gmail.com

* Author for correspondence
} 
reações transfusionais, sendo, primordial a realização de tipagem sanguínea nesta espécie. O estudo objetivou identificar os tipos sanguíneos e a análise hematológica de felinos candidatos doadores de sangue. Foram avaliados 60 felinos, de diferentes raças, peso superior a quatro quilogramas, faixa etária de um a oito anos e clinicamente saudáveis. Após avaliação clínica amostras sanguíneas foram coletadas para hemograma e tipagem sanguínea com o teste imunocromatográfico LabTest $\mathrm{A}+\mathrm{B}^{\circledR}$. Todos os felinos apresentaram nível de hematócrito dentro da normalidade (média 34,12\%), seis (10\%) apresentaram leucocitose e 24 (40\%) trombocitopenia, reforçando a importância de acompanhamento hematológico de animais doadores de sangue. Quanto à tipagem sanguínea, todos os felinos domésticos selecionados como doadores de sangue apresentaram tipo sanguíneo A, sendo este o primeiro estudo sobre as frequências dos tipos sanguíneos felino realizado na região.

Palavras-chave: Transfusão. Gatos. Sangue. Grupo sanguíneo.

The main indication for whole blood transfusion is a decrease in red blood cell mass (Barfield \& Adamantos, 2011), where transfusion has been established as an effective and safe form of treatment for anaemic patients.

In feline medicine, blood typing is of fundamental importance to prevent adverse reactions to transfusions and is important for the prevention of neonatal isoerythrolysis (Spada et al., 2014).

Felines have three blood types which vary by geographic region and breed, with type A being the most prevalent, followed by blood types B and AB (Weinstein, Blais, Oakley, Aronson, \& Giger, 2007). These blood types are differentiated by glycoproteins and membrane glycolipids present in the erythrocytes. The main difference between groups $\mathrm{A}$ and $\mathrm{B}$ is the presence of two glycosamides which differ by an $\mathrm{N}$-acetyl neuroaminic acid (NeuAc) and the N-glycyl neuroaminic acid (NeuGc) (Proverbio et al., 2011). Weinstein et al. (2007) described a new blood type, called Mik, present in three felines that had not previously received transfusions. However, reagents and antisera to identify this are not commercially available.

A feature of feline blood types is the natural presence of high antibody titres against membrane antigens present on the type B erythrocyte wall in type A felines, the presence of natural anti-A antibodies in the blood of type B felines, and the absence of antibodies to both blood types in $\mathrm{AB}$ cats (Weinstein et al., 2007). This feature is important when it comes to the selection of blood donor cats in order to minimize the occurrence of transfusion reactions. Therefore, blood typing in blood donor felines is of paramount importance (Medeiros et al., 2008). Genetically, blood type A is dominant over type $\mathrm{B}$. The third allele $(\mathrm{AB})$ is recessive to $A$ and co-dominant for $\mathrm{B}$, leading to the expression of both molecules A and B (Barfield \& Adamantos, 2011).

Given this, the present study aimed to identify the blood types of feline candidates for blood donation in a veterinary hospital and perform the characterization and haematological analysis of donors.

For this research in a veterinary hospital, clinically healthy cats of different races, both sexes, young adults (i.e., age from one to eight years), and weighing over $4 \mathrm{~kg}$ were selected, according to criteria for feline blood donors described by Haldane, Robert, Marks and Rafee (2004); in addition, the selected cats did not have a history of serious disease or previous blood transfusion.

After authorization and consent of the guardian, a questionnaire was completed about the clinical and epidemiological characteristics of felines, such as body score, street access, presence of ectoparasites, vaccine score, castration, and use of medicines. Pregnant and lactating females were excluded from the study.

For complete haematological evaluation and blood typing, after trichotomy and under aseptic conditions, $4 \mathrm{ml}$ of blood was collected by jugular venipuncture and transferred to tubes containing 
ethylenediaminetetraacetic anticoagulant (EDTA). Samples were processed immediately for complete blood count using a Sysmex pocH 100iV Diff - Roche ${ }^{\circledR}$ automated haematology analyser, and optical microscopic differential counting of all samples was performed by the same operator; the samples were then refrigerated at $4^{\circ} \mathrm{C}$ for a maximum period of 8 hours for blood typing. The haematological evaluation was analysed according to Baker (2015).

Blood typing was performed with a LabTest $\mathrm{A}+\mathrm{B}$ commercial kit $\left(\right.$ Alvedia $\left.^{\circledR}\right)$, following the manufacturer's recommendations and interpretation.

The data obtained in the research were tabulated and analysed descriptively.

A total of 60 felines were included. Of these, $58(96.6 \%)$ had no racial pattern; only two (3.3\%) were purebred, one Persian and one Siamese. Demographically, 36 (60\%) were male and 24
$(40 \%)$ were female, the average age was 4.06 years $(\mathrm{SD} \pm 1.23)$ with a minimum of two and a maximum of seven years and the average weight was 4.89 $\mathrm{kg}(\mathrm{SD} \pm 0.68)$, with a minimum of $4 \mathrm{~kg}$ and a maximum of $7 \mathrm{~kg}$. Clinically, 35 (58.3\%) felines had good body score and 25 (41.7\%) very good body score. Regarding clinical and epidemiological characteristics, 51 (85\%) had street access, 54 (90\%) had animal contact (feline or canine), 45 (75\%) had updated vaccines, $50(83.3 \%)$ were castrated, and only one $(1.66 \%)$ had ectoparasites.

On blood typing, all felines selected as blood donors had blood type A. On haematological evaluation the average haematocrit value, total leucocytes, platelets, and total plasma proteins were $34.12 \%, 13.42 \mu \mathrm{L}^{-1}, 333.82 \mu \mathrm{L}^{-1}$, and $7.65 \mathrm{~g}$ $\mathrm{dL}^{-1}$, respectively. The mean, standard deviation, minimum and maximum value, and median of the haematological components of the felines are shown in Table 1.

\section{Table 1}

Mean, Standard Deviation, Minimum and maximum and median haematological parameters of the 60 feline blood donor candidates

\begin{tabular}{|c|c|c|c|c|c|c|}
\hline & Mean & $\mathrm{SD}( \pm)$ & Minimum & Maximum & Median & Reference values \\
\hline Erythrocytes $\left(\mathrm{uL}^{-1}\right)$ & 7.91 & 1.59 & 5.07 & 12 & 8.09 & $5.0-10.0$ \\
\hline Haemoglobin $\left(\mathrm{g} \mathrm{dL}^{-1}\right)$ & 11.35 & 1.66 & 8 & 14.7 & 11.65 & $8.0-15.0$ \\
\hline Haematocrit (\%) & 34.12 & 5.11 & 25 & 45.9 & 34.35 & $24-45$ \\
\hline VGM (fl) & 43.21 & 3.64 & 36.5 & 50.7 & 42.9 & $39-55$ \\
\hline CHGM (g dL) & 33.15 & 1.19 & 30.2 & 35.4 & 33.2 & $31-35$ \\
\hline Total Leukocytes $\left(\mathrm{uL}^{-1}\right)$ & 13.42 & 4.89 & 5.6 & 25.3 & 13.25 & $5.5-19.5$ \\
\hline Neutrophils $\left(\mathrm{uL}^{-1}\right)$ & 8.11 & 3.4 & 2.2 & 16.4 & 8.1 & $2.5-12.5$ \\
\hline Eosinophils $\left(\mathrm{uL}^{-1}\right)$ & 1.02 & 0.96 & 0 & 3.7 & 0.7 & $0-1.5$ \\
\hline Basophils (uL $\left.{ }^{-1}\right)$ & 0.03 & 0.11 & 0 & 0.6 & 0 & $0-0.2$ \\
\hline Lymphocytes (uL-1) & 4.08 & 1.75 & 1.2 & 10.2 & 4 & $1.5-7.0$ \\
\hline Platelets $\left(\mathrm{uL}^{-1}\right)$ & 333.82 & 114.76 & 103 & 612 & 327 & $300-800$ \\
\hline P.P.T. $\left(\mathrm{g} \mathrm{dL}^{-1}\right)$ & 7.65 & 0.803 & 6.2 & 9.7 & 7.6 & $6.0-8.0$ \\
\hline
\end{tabular}

VGM: Mean Globular Volume; CHGM: Mean Globular Haemoglobin Concentration; P.P.T.: Total Plasm Protein; SD: Standard Deviation. 
In the haematological analysis, seven $(11.66 \%)$ and one (1.66\%) donor candidate felines, respectively, presented erythrocytes and haematocrit above normal values. Mean globular volume was decreased in five $(8.33 \%)$ and mean globular haemoglobin in two $(3.33 \%)$ felines. Regarding the white series, six (10\%) felines presented with leucocytosis. Differential white cell counts revealed neutropenia and neutrophilia in seven $(12.5 \%)$ cats each, in addition to eosinophilia and basophilia in $15(25 \%)$ and three (5\%) felines respectively. Of the cats evaluated, 24 (40\%) presented with thrombocytopenia and $11(18.33 \%)$ with hyperproteinaemia.

Blood typing is essential when it comes to blood transfusion (Spada et al., 2014). In this research conducted on felines selected as blood donors at a veterinary hospital, 100\% had blood type A. Such data corroborate the literature that mentions type $A$ as the most prevalent in the feline population (Guerra, Lacerda, Oliveira, Esteves, \& González, 2007; Medeiros et al., 2008). This result may be associated with the lower proportion of purebred felines in the study population, since according to Klaser, ReineSalz and Hohenhaus (2005) the highest prevalence of type B occurs in purebred felines. However, Gunn-Moore, Simpson and Day (2009) found 100\% of Bengal felines with blood type A, confirming the predominance of this blood type in cats with and without racial definition. Blood type $\mathrm{AB}$, although considered rare, has already been reported in studies conducted in the feline population of Brazil (Guerra et al., 2007; Medeiros et al., 2008), however, the absence of this blood type, and also of the blood type B can be explained by the limited number of felines sampled in this study.

A study by Gurkan, Arikan, Ozaytekin and Dodurka (2005) analysed the presence of alloantibodies in felines and noted the presence of high anti-A antibody titres in type B felines, and low anti-B antibody titres in Type A felines. Of the low titres found in type A felines, the presence of these antibodies in $70 \%$ of felines with this blood type, and type A being the most prevalent blood type in the feline population (as well as in the population of this study), a high risk of transfusion reactions in this species can be inferred. Such analysis reinforces the one described by Medeiros et al. (2008) about the importance of determining the most prevalent blood groups in the region, in addition to selecting permanent blood donors in order to decrease the rate of transfusion reactions; these were the objectives of this study as well. Although the number of felines surveyed is low and not representative of the municipality, such data may still indicate a predominance of blood type $\mathrm{A}$ in felines, this being the first study of blood typing in this species in the municipality.

All felines evaluated had a body score, age, and weight considered ideal for blood donation, according to Gibson (2007). According to this author, there is no sexual predilection for a feline to donate blood, but castrated felines should be preferred, due to their gentler temperament. In this study, there was no predominance of felines in terms of gender, but $83.3 \%$ were castrated, reinforcing the opinion by Gibson (2007) about their easier containment.

One of the important epidemiological characteristics observed in $80 \%$ of selected cats was free access to the street. According to Hohenhaus (2004), felines with street access should preferably not be used as donors due to the higher risk of contact with potentially transmissible infectious diseases. In addition, 90\% lived with other animals. However, these characteristics, while important, should be considered along with other aspects such as clinical evaluation, laboratory tests, and vaccine history, as $45(75 \%)$ had an updated vaccination history. Nevertheless, the need for testing for infectious diseases, especially those listed on the screening panel for blood donor cats, such as feline viral leukaemia virus (FeLV) and feline immunodeficiency (FIV), in addition to Mycoplasma spp. and Bartonella spp. (Pennisi et al., 2015). 
According to the haematological analysis, like Baker (2015) the felines presented adequate levels of the red series. The number of felines presenting with neutropenia in the study group reinforces the results described by Barfield and Adamantos (2011) on the importance of performing differential leucocyte counts prior to blood donation and testing for infectious agents in blood donor felines, however such research was not the purpose of this study. Another haematological change found in $40 \%$ of felines was thrombocytopenia, but this result may be due to the stress of blood collection culminating in transient thrombocytopenia. Such analysis is supported by the presence of platelet aggregates in $12(50 \%)$ of the 24 cats with thrombocytopenia, since according to Granat, Geffré, Braun and Trumel (2011), platelet aggregation occurs rapidly, leading to incorrect analysis and diagnosis of thrombocytopenia. However, feline follow-up and research into other causes of thrombocytopenia should be conducted.

This research demonstrated that the blood donation candidate felines did not present with anaemia, but thrombocytopenia was a relatively common finding in animals, reinforcing the importance of haematological follow-up of blood donor animals. As for blood typing, all domestic felines selected as blood donors had blood type A, this being the first study on the frequency of feline blood types conducted in the region.

\section{Ethics Committee}

The project was approved by the Ethics Committee for the Use of Animals of the Federal University of Mato Grosso, Brazil, under protocol number 23108.174477/2016-01.

\section{Conflict of Interest Statement}

The authors declare no conflict of interest.

\section{References}

Baker, D. C. (2015). Diagnóstico das anormalidades de hemostasia. In M. A. Thrall, G. Weiser, R. W. Allison, \& T. W. Campbell (Ed.), Hematologia e bioquímica clínica veterinária (2a ed., pp. 399-439). São Paulo: Roca.

Barfield, D., \& Adamantos, S. (2011). Feline blood transfusions: a pinker shade of pale. Journal of Feline Medicine and Surgery, 13(1), 11-23. doi: 10.1016/j.jfms.2010.11.006

Gibson, G. (2007). Transfusion medicine. In: L. King, \& A. Boag (Ed.), Manual of canine and feline emergency and critical care (2a ed., 215-226). United Kingdom: BSAVA.

Granat, F., Geffré, A., Braun, J. P., \& Trumel, C. (2011). Comparison of clumping and complete blood count results with Sysmex XT-2000iV in feline blood sampled on EDTA or EDTA plus CTAD (citrate, theophylline, adenosis and dipyridamole). Journal of Feline Medicine and Surgery, 13(12), 953-958. doi: 10.1016/j.jfms.2011.07.014

Guerra, T. A., Lacerda, L. A., Oliveira, S. T., Esteves, V. S., \& González, F. H. D. (2007). Tipagem sanguínea em felinos: 148 gatos domésticos na rotina laboratorial do Lacvet-UFGRGS. Acta Scientiae Veterinariae, 35(Supl. 2), 573-574.

Gunn-Moore, D. A., Simpson, K. E., \& Day, M. J. (2009). Blood types in Bengal cats in the UK. Journal of Feline Medicine and Surgery, 11(10), 826-828. doi: 10.1016/j.jfms.2009.03.008

Gurkan, M., Arikan, S., Ozaytekin, E., \& Dodurka, T. (2005). Titres of alloantibodies against A and B blood types in non-pedigree domestic cats in Turkey: assessing the transfusion reaction risk. Journal of Feline Medicine and Surgery, 7(5), 301-305. doi: 10.1016/j.jfms.2005.03.003

Haldane, S., Robert, J., Marks, S. L., \& Rafee, M. R. (2004). Transfusion medicine. Compendium of Continuing Education for the Practicing Veterinarian, 26(7), 502-518.

Hohenhaus, A. E. (2004). Importance of blood groups and blood group antibodies in companion animals. Transfusion Medicine Reviews, 18(2), 117-126. doi: 10.1016/j.tmrv.2003.12.003

Klaser, D. A., Reine-Salz, N., \& Hohenhaus, A. E. (2005). Red blood cell transfusions in cats: 126 cases (1999). Journal of American Veterinary Medicine Association, 226(6), 920-923. doi: 10.2460/ javma.2005.226.920 
Medeiros, M. A., Soares, A. M., Alviano, D. S., Eizemberg, R., Silva, M. H. da, \& Almosny, N. R. (2008). Frequencies of feline blood types in the Rio de Janeiro area of Brazil. Veterinary Clinical Pathology, 37(3), 272-276. doi: 10.1111/j.1939165X.2008.00051.x

Pennisi, M. G., Hartmann, H., Addie, D. D., Lutz, H., Gruffydd-Jones, T., Boucraut-Baralon, C., \& Mostl, K. (2015). Blood transfusion in cats $\mathrm{ABCD}$ guidelines for minimising risks of infectious iatrogenic complications. Journal of Feline Medicine and Surgery, 17(7), 588-593. doi: 10.1177/1098612X15588449

Proverbio, D., Spada, E., Baggiani, L., Perego, R., Milici, A., \& Ferro, E. (2011). Comparison of gel column agglutination with monoclonal antibodies and card agglutination methods for assessing the feline $\mathrm{AB}$ group system and a frequency study of feline blood types in northern Italy. Veterinary Clinical Pathology, 40(1), 32-39. doi: 10.1111/j.1939165X.2011.00286.X
Spada, E., Miglio, A., Proverbio, D., Antognoni, M. T., De Giorgi, G. B., Ferro, E., \& Mangili, V. (2014). Signalment and blood types in cats being evaluated as blood donors at two Italian University blood banks. Veterinary Medicine International, 2014,1-3. doi: $10.1155 / 2014 / 704836$

Weinstein, N. M., Blais, M. C., Oakley, D. A., Aronson, L. R.,\&Giger,U.(2007).Anewly recognizedblood group in domestic shorthair cats: the Mik red cell antigen. Journal of Veterinary Internal Medicine, 21(2), 287292. doi: 10.1892/0891-6640(2007)21[287:anrbgi]2 .0.co;2 